Euskal ikerketen aldizkaria | Revue d'études basques |

Revista de estudios vascos | Basque studies review

$21 \mid 2018$

Numéro XXI

\title{
36ko gerrako Euskadi: Oroimen kritikoa bi berrirakurketa nobeleskotan
}

\section{Alexander Gurrutxaga Muxika}

\section{OpenEdition}

Journals

Édition électronique

URL : https://journals.openedition.org/lapurdum/3767

DOI : 10.4000/lapurdum.3767

ISSN : 1965-0655

Éditeur

IKER

\section{Référence électronique}

Alexander Gurrutxaga Muxika, «36ko gerrako Euskadi: Oroimen kritikoa bi berrirakurketa

nobeleskotan», Lapurdum [Linean], 21 | 2018, Sarean emana----an 01 janvier 2018, kontsultatu 23

février 2022. URL: http://journals.openedition.org/lapurdum/3767 ; DOI: https://doi.org/10.4000/

lapurdum.3767

Creative Commons - Attribution - Pas d'Utilisation Commerciale - Pas de Modification 4.0 International - CC BY-NC-ND 4.0 


\title{
36ko gerrako Euskadi: Oroimen kritikoa bi berrirakurketa nobeleskotan
}

\author{
Alexander Gurrutxaga Muxika \\ Euskal Herriko Unibertsitatea UPV/EHU \\ alexander.gurrutxaga@ehu. eus
}

LABURPENA

Artikulu honen helburua da oroimen kritikoari buruzko zenbait gogoeta plazaratzea Juan Luis Zabalaren Agur, Euzkadi eta Ramon Saizarbitoriaren "Asaba zaharren baratza" nobelen azterketa konparatutik abiatuz. Testuen ezaugarri nagusi batzuei behatuz, ondorio eta eztabaidagai zenbait ateratzen dira memoria egiterakoan baliatzen duten ikuspegiaz eta tonu narratiboaz.

\section{Sarrera ${ }^{1}$}

Artikulu honen helburua da Gerra Zibila piztu zenean Euskal Herrian gertatutako gertaera biren berrirakurketa nobeleskoak aztertu eta memoriari buruzko gogoeta zenbait plazaratzea. Konkretuki, Juan Luis Zabalaren Agur, Euzkadi eta Ramon Saizarbitoriaren "Asaba zaharren baratza" 2 testuei begiratuko diegu. Biak ala biak 2000. urtean argitaratuak dira; lehenak Lauaxetaren fusilamendua dakarkigu, eta bigarrenak, berriz, Sabino Arana-Goiriren hobiratzea

1 Artikulu honen jatorria 2014ko otsailean emandako hitzaldi bat da, Mikel Ayerbek eta Lourdes Otaegik EHUko Letren Fakultatean antolaturiko Euskal Literatura eta Memoria mintegiaren bigarren saiorako ('Berrirakurketak eta memoria') prestaturikoa. Han azaldutakoak daude artikuluaren oinarrian. Gerora, aztergaiaren inguruko ekarpen gehiago egin dituzte ikertzaileek; guztien artean, azpimarratzekoa da Izaro Arroitaren doktore tesia: Ramon Saizarbitoriaren nobelagintza memoria ikasketen ikuspegitik (2015). Neurri apalean, sinatzaileak ere jarratu du gaia (ikus bibliografia: 2017, 2019 eta 2019). Bidenabar, eskerrak eman nahi dizkiot Lourdes Otaegiri, egindako iradokizunengatik.

2 Saizarbitoriaren "Asaba zaharren baratza” nobela ote den ala ez eztabaidagarria da, baina ez da genero sailkapena hemen eztabaidatu nahi duguna eta, beraz, nobela labur nahiz narrazio luze, testu nobeleskotzat hartuko dugu. 
eta desehorztea. Testu bi hauek egiten duten historiarako hurbilketa oinarritzat hartuz, berrirakurketa bien tonuan dagoen aldea aztertu eta zenbait gogoeta egingo ditugu.

Gatazka gai nagusitzat duen literaturan kontzeptu esanguratsua gertatzen da "distantzia", hainbat eta hainbat testutan ikus baitaiteke urrunekoaren eta gertukoaren, edo, bestela, urrunekoaren eta "gurea"ren arteko erlazionatze bat. Aipaturiko distantzia espaziala izan daiteke; halakoa da Joseba Sarrionandiaren Moroak gara behelaino artean? (Pamiela, 2010) saiakeran edo Koldo Izagirreren Non dago basque's Harbour (Susa, 1997) poema liburuan. Zabalaren eta Saizarbitoriaren testuen kasuan, ordea, distantzia tenporala da, eta testu biek planteatzen dute iraganaren berrirakurketa bat, gure historiaren berrinterpretazio bat; finean, memoria kritiko ariketa bat.

\section{Agur, Euzkadi eta Asaba zaharren baratza}

Juan Luis Zabalaren Agur, Euzkadi eta Ramon Saizarbitoriaren "Asaba zaharren baratza" (hemendik aurrera, $A E$ eta $A Z B$, hurrenez hurren ${ }^{3}$ ) azterketaren ikergaitzat ezartzerakoan, eztabaidaren erdigunean jarri nahi dugun puntua berrirakurketen nolakotasuna da; hau da, begiratu nahi dugu narratzailearen begirada nolakoa den eta memoria ariketaren konnotazio nagusiak zein diren. Izan ere, bi testuok mende hasierako gertaera jakin batzuk berrirakurtzen dituzte, eta horiek literarioki birsortzean, tonuari dagozkion ezaugarriak gehitzen dizkiote narrazioari, planteatzen den interpretazioaren zantzuak erakusten dituztenak.

Nobela biek dituzte antzekotasun esanguratsu zenbait. Biak dira, arestian esan bezala, 2000. urtekoak, eta biek dute titulutzat Pizkundeko poema baten izenburua. Zabalarenak Esteban Urkiaga 'Lauaxeta'ren “Agur, Euzkadi” dakarkigu, eta Saizarbitoriarenak Jose Maria Agirre 'Xabier Lizardi'ren "Asaba zaharren baratza". Lauaxetarena tonu epiko aski nabaria duen poema da; Lizardirena, berriz, poetaren obran oso markatua den poema, Lizardi poeta nagusiki lirikoa izanik, "Asaba zaharren baratza" subjektu kolektiboa duten poemetarik bat baita, gai politiko eta historikoak lantzen dituena.

Bestalde, bi testuetan garai hartako pertsona bat hobitik ateratzen da: AEn pertsonaia historikoa, Lauaxeta, berpiztu egiten da, eta $A Z B n$ Sabino Arana desehortzi egiten dute. Bi kasuetan, gainera, pertsona historikoa hobitik ateratzeak orduko gertaera gaurkoarekin lotzeko bidea ematen du; alegia, Lauaxetak, hil eta 60 urtera berpizten delarik, mende amaierako egoerarekin egiten du topo, eta Sabino Arana (1903an hila) 1937an desehorzten dutelarik, garai hartan

3 Zabala, Juan Luis. 2000. Agur, Euzkadi. Iruñea: Susa. Saizarbitoria, Ramon. 2000. Asaba zaharren baratza. In Gorde nazazu lurpean. Donostia: Erein. 401-464. 
gaztea izan eta mende amaieran oraindik bizirik dagoen jendearekin elkartzen da. Horrela, beraz, lotzen dira bi garai historiko.

Pertsonaia historikoaren ondoan, bi nobeletan dago gaurko pertsonaia bat, eta bietan da (Julen $A E$ n, Polikarpo $A Z B n$ ) pertsonaia deserrotua. Era berean, testu bietan lotzen da protagonista maitasun edo amodio istorio batean; bikote harremanik ez dago testuaren hasieran, bi pertsonaiak daude erabat deserrotuak, baina bietan ere nobelak aurrera egin ahala maitasun istorioak bilakabide positiboa egiten du, eta amodio istorioaren gauzatzeak -edo gauzatuko delako iradokizunak-ixten du nobela.

Azkenik, baina jakina, ez garrantzia gutxiagorekin, esan behar da bi nobeletako protagonistek egiten dutela ibilbide bat. Batetik, bidaia fisikoa da, eta espazioek esangura berezia dute gai historikoei loturik; bestetik, ezagutzazko bidaia ere bada, eta tramak aurrera egiten duen heinean pertsonaiak historiari buruz gehiago daki. Postmemoriaz hitz egin behar dugu, beraz: eten historikoa gertatu da, egungo protagonistak ez dira gerraren lekuko zuzenak, baina euren bilaketak oroimen historikoaren inguruko bersemantizatze bat dakar. Horrekin batera, irakurleak ere memoria ariketa egiten du, orriak pasa ahala historiaren ezagutza eta berrirakurketa prozesua gauzatzen baititu. Irakurketaren unean, beraz, memoria norbanakoaren eta jendartearen arteko zubian mugitzen da. Pio Perez Aldasorok argitaratutako Joxe Zapirainen bertso-malkoak lanean (2013) honela dio memoriari dagokion esparruaz:

\footnotetext{
Dena den, ezin dugu esan memoria ezaugarri pertsonala dela, memoria soziala baita, gizarteari dagokiona. Maurice Halbwachs soziologoak jite soziala eman zion memoriari. Egile horrek ${ }^{4}$ honako hau aldeztu zuen: norbanakoaren oroimena gizarte koadro edo markoen barnean mugitzen da beti. (2013:102)
}

Eta aurrerago, jarraitzen du Perez Aldasorok: “Azken finean, memoria gizartekoa da, eta taldekoa bihurtzen da banakoek partekatzen dutenean, denen artean ematen diote gorputza narrazio, sinbolo eta erritualen bidez" (2013:105). Esan daiteke, hortaz, narrazio literarioaren irakurketa esperientzia partekatzailea dela, eta irakurleak zubiak eraikitzen dituela kolektiborantz, marko sozialean zentzua hartzen duen memoriarantz.

Orain arte Juan Luis Zabalaren eta Ramon Saizarbitoriaren testuen arteko antzekotasun zenbait aipatu ditugu. Gehiago egon daitezke, jakina, baina ezaugarri hauek garrantzitsuak dira, eta kontuan hartzekoak memoria lantzen duen literaturan agertzea ohikoa izan daitekeen neurrian.

4 Halbwachs, Maurice (2004) Los marcos sociales de la memoria. Bartzelona: Anthropos. 


\section{Agur, Euzkadi: berrirakurketaren osagai epikoak}

Juan Luis Zabalaren nobelak berreraikitzen dituen gertakari historikoak arnasa epikoak inguratzen dituela frogatzeko saiakera egingo dugu jarraian. Epika, merezi du gogoratzea, "gertakizun eta ekintza gogoangarriak -bortxazkoak edo heroikoak gehienetan- kantatzen dituen generoa da", Literatura Terminoen Hiztegiari jarraitzen baldin badiogu (2008:211). Epikaren azpisail historikoaz ari garenean, garrantzitsuena ez da gertakizun historikoaren berri zehatza eman edo birsortze ahalik eta fidelena egitea, baizik eta gertakizun horietarik abituz sortzen den zirrara estetikoa (LTH 2008:213). Gogoan hartu behar da, era berean, epikak historikoki zein leku duen: "Europako nazioen osatze prozesuan, ahozko tradizioak epopeiarik eskaini ez dien herri anitzetan epopeiagile jantziak agertu ziren" (LTH 2008:211). Epika elementu konstantea da Europako estatu modernoen sorreran; gure kasuan, ikuspegi horren baitan ulertu behar da Aitzolen proiektu kulturala, eta baita Orixeren Euskaldunak poema nazionalaren ideia ere.

Juan Luis Zabalaren nobelan bereziki bi ardatzen inguruan nabari delakoan gaude osagai epikoen presentzia: alde batetik, Lauaxetaren figura historikoa karakterizatzen duten elementuetan; eta bestetik, Gerra Zibileko Euskadiren eta Espainiar Trantsizio deiturikoaren garaiko Euskadiren artean nobelak egiten dituen loturetan.

\subsection{Lauaxetaren figura}

Lauaxeta ez da, $A E \mathrm{n}$, poeta gisa bakarrik agertzen; hau da, narrazioaren baitan, poeta izatea bezain garrantzitsua da afusilatua izatea. Are gehiago, fusilamenduarena ez bezala, bere irudi literarioa umoretik asko duen tonuarekin tratatzen da:

\footnotetext{
Nik? Lauaxetaz? Tira, nik, egia esan, aukeran, ez zaitez haserretu baina Lizardi nahiago dut, errazago sartzen zait, bai, samurragoa zait, gertukoagoa, beharbada neu ere giputza naizelako, ez dakit... Baina Lauaxeta ere estimatzen dut. Ausarta zen, berrizalea... Eta sutsua, epikoa batzuetan, eta sekulako zirrara eragiten dute haren poema batzuek, batez ere gero nola hil zen aintzat hartuz gero... (2000:37)
}

Liburuaren azalean, Andueza margolaria Lauaxetaren betaurreko margotuak (gorriak) jantzirik azaltzen da. Elementu sinboliko esanguratsua bihurtu dira, dagoeneko, betaurrekook, eta kasu honetan berehala eramaten gaituzte Koldo Izagirreren Balizko erroten erresuma (Susa, 1989) liburuko 'Lauaxetaren betaurrekoak' atalera. Gogoratzekoa da atal honetako azken poemaren amaiera: "Ezin hazaket maita afusilaturik besterik" (1989:28). Zabalaren nobelan ere Lauaxeta 
afusilatua izana funtsezkoa da gai aldetik, eta gainera, kontuan hartzekoa da Iratxe Retolazak ${ }^{5}$ Koldo Izagirreren poema aztertzen duelarik esaten duena ere; hau da, "Lauaxetaren hilketa euskaltzaletasunari eginiko erasotzat errepresentatzen" dela (2009:1099).

Osagai epikoekin jarraituz, arreta berezia merezi dute nobelan ematen diren Lauaxetaren testuetako aipuek. Tituluak eta nobelaren hasierako hiru aipuak "Agur, Euzkadi" eta "Azken oyua" poematatik hartuak dira, hain juxtu ere, Lauaxetak afusilatua izateko zain zegoela idatzi zituen poematakoak. Bernardo Atxagak Markak (Pamiela, 2007) lanean idazten duen bezala, "olerkiak idazten ditu Esteban Urkiagak ere, baina ez Parisen edo Londresen, Gasteizko presondegian baizik, bere exekuzio orduaren zain. Olerkiak otoitzak dira, eta, aldi berean, familia eta adiskideentzako agur eskutitzak" (2007:39).

Adierazgarriak dira kapituluen izenburuak ere, bostetik lauk Lauaxetaren tonu poetiko epikoa errepresentatzen baitute. Lehenengoa da salbuespena, 'Arrats beheran' tituluak irakurketa sinbolikoa iradokitzen baitu, pertsonaia etsituaren karakterizazioari atxikia. Beste izenburuek, ordea, guztiek iradokitzen dute irakurketa epikoa. 'Mendietara' tituluak mendiak Pizkundean zuen sinbolismo literario eta politikoa dakarkigu, 'Bide berriak' ere aldarri poetiko eta politikoa da, eta 'Hil ginenon hatsa'k, "Azken oyua" poematik atereak, memoriaren aldarria dakar berekin. Guztien artean "Ontzi-puntan soinutsik" kapitulu-izenburua nabarmendu daiteke, Lauaxetaren "Itxasora" poematik ateratako lerroa. Poema epikoa da berau, zentzurik fidelenean, testuarteko erreferentzia zuzena Odisea baitu. Aipatu behar da, bidenabar, Bidebarrijak liburuko azken orriko "Uarra" ezagunean Lauaxetak adierazten duela aberria poesia baino garrantzitsuagoa dela: "Eztot gixonakaitik egin, Aberrijagaitik baño. Olerkari nazala agertutiari enago, izkuntza onetan be gogai batzuk azaldu daikeguzala erakustiari bai'ostera" (1931:142). Zabalaren nobelan ere, Lauaxeta pertsonaiak horixe aldarrikatzen du: "Badira poesia baino garrantzi handiagoko kontuak. Aberria eta uzkurtza, adibidez. Aberria eta uzkurtza batez be. Euskal Herria eta Jaungoikoa" (2000:84). Lauaxetaren figura literarioa poeta engaiatuarena da, beraz, poeta gudari eta afusilatuarena.

Azkenik, merezi du gogoratzea Lauaxeta Federico García-Lorca poeta espainiarrarekin alderatzen dela testuan (2000:124-125): biak izan ziren poetak, biak politikoki espainiar Errepublikaren aldeko kokatuak, eta biak afusilatuak. Koldo Izagirrek ere egin zuen lotura hori, aipaturiko 'Lauaxetaren betaurrekoak' ataleko lehen poeman: 'Nik ere banuke nahi izanez gero / -Federico, Miguel- / Poeta baten izena ahotan hartzeko / (...) / Ezizenezko izen xume bat / -Lauaxeta-..." (1989:25).

5 Retolaza, Iratxe (2009) "Gernikako bonbardaketa euskal literaturan: errepresentazio eta begirada poetikoak" in Euskera, monografikoa, Gerra Zibila eta euskal literatura. Bilbo: Euskaltzaindia. 1079-1108. 


\subsection{Garai bien arteko lotura}

Tonu epikoa nagusitzen den beste esparrua 36ko gerraren garaia eta mende amaierako garaia lotzen dituen pasarteei dagokio. Julen Lamarain protagonistak eta Esteban Urkiagak abiatzen duten bidaiak kutsu epikoa du; asko du abenturatik, baina batez ere lurralde nazionalean egindako ibilbide epikoa da, bidaia "quijotesco" bat. Lurraldearen errekonozimendua bera oso esanguratsua da, Ángel Castiñeirak Naciones imaginadas (2005) lanean dioskun bezala, historiaren kokagune bihurtzen baita espazioa:

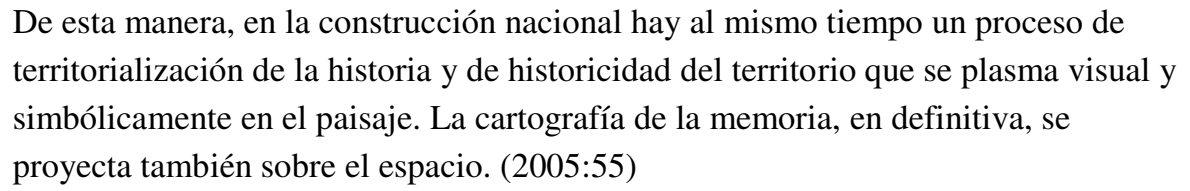

De esta manera, en la construcción nacional hay al mismo tiempo un proceso de territorialización de la historia y de historicidad del territorio que se plasma visual y simbólicamente en el paisaje. La cartografía de la memoria, en definitiva, se proyecta también sobre el espacio. (2005:55)

Bestalde, azpimarratzekoak dira Kixoteri egindako testuarteko erreferentziak. Alde batetik, bikote xelebreak Don Quijote eta Sancho Panza gogorarazten dizkigu. Bestetik, Leitzako haizeerroten agerpenak ere lotura egiten du hango erroten sekuentzia ezagunarekin; are gehiago, beste behin ere Koldo Izagirreren poema liburua dakarkigu eszenak gogora: izan ere, Balizko erroten erresumak titulutik bertatik deitzen dio espainiar nobelari, eta paralelismo bat egiten du Espainiaren kantu edo narrazio epikoen eta balizko euskaldunen artean -beste behin, arestian aipatu "distantzia"z baliatuz-. Hortaz, Izagirrek markatzen zuen ausentziari Zabalaren nobelak erantzun egiten dio nolabait.

Garaien arteko lotura zuzenetako bat nobelaren azken atalean gertatzen da. Erniopean, Zelatunen 6 , Julenek eta Lauaxetak Juan Paredes Manot "Txiki” eta Anjel Otaegirekin egiten dute topo. Orduan, hiru pertsona historikoak Ernioko gailurrean izatekoa den bilerara joaten dira (2000:140-141). Lauaxeta, Frankismoaren lehen fusilatuen irudia da, 36ko gerrako fusilatuena; Txiki eta Otaegi, 1975ean, Frankismoaren azken fusilatuak dira: esan daiteke lotura horren mahaigaineratzea, testuinguratze historikoa badagoen ala ez eta horren eztabaidagarritasun kontzeptuala albo batera utzirik, tonu epikoan aurkezten dela.

Gisa horretako beste lotura bat, ziurrenik nagusia, gerra galdu izanak markatzen du -Saizarbitoriaren literaturan ere galtzailetzaren ideia zentrala da- Lauaxeta pertsonaiak honela esaten dio Goizederri: "Gure hizkuntza, gure herria, gure... gure arbasoek galdutako guda gogor eta ankerra... Hori guztia berdin jan?” (2000:90). Euskal subjektu modernoaren traumatzat ageri da hor gerra galdu izana, eta subjektu horren identitatea definitzerakoan osagai ezinbestekotzat defendatzen da ("Hori guztia berdin jan?"). Identitateak, iraganaren eta

6 Zelatun bidegurutze historiko garrantzitsua da. Besteak beste Estrabonek lekukotuta dago guda kantabroetan euskaldunek Zelatunen eutsi omen ziotela Augustoren erasoari. 1936an ere guduzelai bihurtu zen Ernio ingurua. 
orainaldiaren jarraitutasunari loturik dagoen neurrian, kontinuitatea eskatzen du, eta iraganeko traumen oroimenak orainaldiko subjektuaren izaera definitzeko ahalmena du. Castiñeirak honela zehazten du memoria kolektiboaren funtzioa:

\begin{abstract}
Las naciones, al igual que decíamos de la identidad personal, necesitan también continuidad (temporal, demográfica, territorial, cultural, política), reconocimiento interno y externo, dar coherencia y diferencialidad a las vivencias compartidas de sus miembros y (...) construir e interpretar su identidad narrativa a través de su propia memoria biográfica: la memoria colectiva. (2005:48-49)
\end{abstract}

Alde horretatik, Lauaxeta protagonistak eskatzen dituen traumaren errekonozimendua (gerra galdua) eta oroimen kolektiboa nazioaren identitate eraikuntzari atxikirik agertzen dira. Hain zuzen ere, azken kapituluan Julenek eta Lauaxetak bat egiten dute ideologikoki. "Ni zuek nauk, neurri batean behintzat" (2000:137), aitortzen du, eta jarraitu:

\begin{abstract}
Alderdi edo arlo askotan behintzat, zuenaren gisakoa izan zuan, 40, 50 edo 60 urte geroago gure haurtzaroa. Zuenen antzekoak, alderdi edo arlo askotan behintzat, gure kezkak, nahiak, ametsak, ezinak eta borrokak. Zuenaren antzekoa, azken batean, gure galtzailetza. (2000:137)
\end{abstract}

Segidan Urtzi Urrutikoetxearen poema liburua aipatzen da, eta egoera hura eta hau berdintzat hartu: "Borroka galduetatik gatoz dik izenburu Urtzi Urrutikoetxea poeta gaztearen lehen liburuak. 60 urte, beraz, gutxi gorabehera lehen zeundeten, lehen geunden lekura heltzeko" (2000:137-138). Iragan traumatikoa orainaren elementu definitoriotzat eta justifikatzailetzat hartzean dago, gure irakurketaren arabera, tonu epikoaren nagusitasuna. Puntu horretan bat egingo luke memoria ikuspegiak Castiñeirak aipaturiko lanean definitzen duen memoria mota batekin:

La de aquellos que defienden la fuerza crítica de la memoria y el testimonio interpelador del sufrimiento de las víctimas (...) como imperativo moral, como orientación básica o intención práctica para toda acción relacionada con la libertad humana. (2005:62)

\title{
4. Asaba zaharren baratza: karakterizaziotik ikuspegi historikora
}

$A Z B \mathrm{n}$ idazleak aurkezten duen berrirakurketaren tonua definitzeko funtsezkoa da protagonisten karakterizazioari begiratzea. Lourdes Otaegik (2009:11) iradokitzen duen bezala, Saizarbitoriaren obra honetan sinplifikatu egin dira kontakizunaren elementu egituratzaileak, baina, aldiz, pertsonaiek garrantzia handia hartzen dute. Gure gaiari dagokionez, karakterizazioaren eta memoria egiteko moduaren artean erlazio zuzena dagoela esan daiteke. Ur Apalategik ohartarazten digu kritikoek Bihotz bi nobelaren dimentsio identitarioa azpimarratu dutela; are gehiago dio: "Gure izaera nazionalaz eginiko gogoeta gisa ere hartua izan da Bihotz bi, arrazoiz, nire uste apalean. Eta hori aspektu historikoak ematen dio obrari, 
inolako dudarik gabe" (2009:1118). Saizarbitoriaren testu(et)an, beraz, identitatea historiarekin lotura askaezinean agertzen zaigu.

Narrazioak hamabi atal ditu, eta lehen bi atalak osoki eskainiak zaizkio pertsonaien izaera karakterizatzeari. Protagonista nagusia ahula da, izenetik hasita, eta gai hori funtsezkoa da narrazioan, bai pertsonaien harremanei dagokien mailan, bai eta historiaren berrirakurketari lotuta ere. Hain justu ere, lehen esalditik markatua dago protagonistaren identitatearen esparrua: “Aitak Sabin ipini nahiko zidan izena". Hortik aurrera bere identitatea definitzen duen hainbat aipamen dago, eta oro har aitak eta semeak bat egiteko duten zailtasuna erakusten dute: "ez nintzela nire aitaren semerik maitatuena, bakarra izan arren", "eduki ezin izan zuen Sabin izeneko seme baten nostalgia zuela", "izan beharko nukeena izatera iritsi ez naizen norbait naizela", "ez naizela nire aitak espero zuena".

Aitari dagokionez, ordea, semearen sentimenduak konplexuak dira. Alde batetik, aita ohe alboan jarri eta hanken gainean esertzen denean, semea, "gehiegizko errespetua" dela eta, ez da gai min ematen diola esateko (2000:403). Baina, era berean, semeak badaki "aita ez zela nortasun handiko gizona" (2000:409); "une berarentzat ezin zoriontsuago haietan hain ahula iruditzen baitzitzaidan, antza, non, esan dudan bezala, nahiago nuen bere zama isilean jasan" (2000:428). Hemendik aurrera, pertsonaien karakterizazioa historiaren berrirakurketa izango denarekin lotzen hasten da. Ezinbestean gogoratu beharrekoa da bigarren atalaren amaiera:

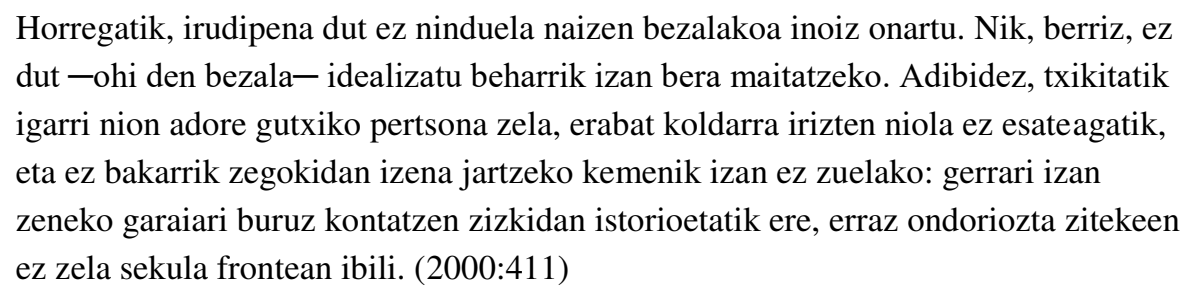

Ahapaldi horrek lotzen ditu esplizituki aita-semeen arteko harremana eta aitak historian izan zuen funtzioaren pertzepzioa. Semeak epikaren eta imaginarioaren beharrik ez du aita maitatzeko, besteak beste, lotura fisikoa hor dagoelako. Baina, era berean, aitaren figura historikoa, frontean ibili ez zen koldarrarena, erabat etsigarri eta patetikoa zaio, eta irudi horrekin bat egiteko duen zailtasuna azaleratzen da. Esan daiteke hauxe dela Saizarbitoriaren narrazioaren tonu nagusiaren lehen oinarria: idealizaziorik eta epikarik eza mahai gainean jarrita, ikuspegi antiepikoa nagusitzen da. Apalategik adierazten duenaren arabera, idealizazioaren kontrakoa da, hain zuzen, Saizarbitoriak planteatzen duena: "Historia, hortaz, izan dadin gerra zibila, ala beste edozein gertaera, Saizarbitoriaren pertsonaientzat, desmitifikatu beharreko materia bat da, norberaren ez heroikotasunaren edo miseriaren zama eramangarriago bihurtze aldera" (2009:1120).

$A E n$ bezala, $A Z B n$ garrantzia handia du "galtzailetza"k, baina ez Zabalaren nobelako konnotazio berberekin. Iñaki Aldekoak Gerra Zibila Ramon Saizarbitoriaren narraziogintzan (2009) lanean dioenez, 
Bai 'Gudari zaharraren gerra galdua'n, bai 'Asaba zaharren baratza'n, bietan gogoratzen zaigu eAJ hark ondorengoei utzitako kapital moral bikainena egon behar zuten lerroan egon edo defenditu behar zuten kausaren alde egin izana izan zela. (2009:1140)

$A Z B n$ galtzailetza ez da orainaldiko identitate kolektiboaren osagai definitzaile positiboa, izaera duina eta errugabetasuna bermatuko lituzkeen elementua baizik: "gerra duintasunez galdu izateagatiko harrotasuna", "galtzaile izatea berez dagokienez, duin izateko galtzea beste erremediorik ez dutenekin” (2000:414).

Izenaren gaia berriz hartuz, alderdi horrek interpretazioan harago joaten lagundu behar digu. Koka dezagun laburki, ezer baino lehen, gertaera historikoa bere testuinguruan. Sabino Arana 1903an hiltzen da eta Sukarrietan lur ematen diote. 1937an, Gernikaren bonbardaketa gertatu eta egun batzuetara, nazionalek hilobia profana dezaketen beldurrez, EAJko zenbait kidek desehorzten dute, eta sekretuan Zallako hilobi batera eramaten. 1989ko urtarrilaren batean ateratzen du EAJk gorpua Zallako hilobitik Sukarrietara itzultzeko. Ordu arte, Arana Goiriren gorpua non zegoen bi pertsonek bakarrik zekiten: Luis Maria Retolazak eta Sabin Zubirik - ohar bedi irakurlea izenaren kointzidentziaz-. Azkenik, kontuan hartzekoa da Sabino Aranaren izen osoa zein zen, horrexetan baitago $A Z B \mathrm{k}$ aurkezten duen egoeraren azalpenaren muinetako bat: Sabino Polikarpo Arana-Goiri zen politikaria izenez. Paradoxikoki, protagonistak errua botatzen dio bere aitari Sabinoren izena jarri ez ziolako, eta hortik datorkiolako, izenaren faltatik, izateko ezina. Polikarpok uste du jaio berritan bizia salbatu zion mojaren ordenaren izena jarri ziola aitak, baina egiazki badarama Sabinoren izena: izen ezkutua, ordea, ezezaguna. Eta izen ezagunaren eta izen ezezagunaren arteko bereizkuntza funtsezkoa da Saizarbitoriak eraikitzen duen irakurketa historikoan. Lourdes Otaegik, beste ildo batetik, honakoaz ohartarazten gaitu “Asaba zaharren baratzaz oraindik" (2002) lanean: Lizardiren poemak badu eskaintza bat, hain justu ere zera dioena: "Barrena'tar Polikarpa, adiskide min ta abertzale yatorrari, biotzez". Polikarpo Barrenaren eta Lizardiren artekoan balegoke, beraz, interpretaziorako beste helduleku bat.

Bestalde, aitaren lagun Feliperen alabak Sabine du izena, bere aita ausartzen baita alaba Sabine bataiatzen -nahiz eta, oraingoan eskema alderantzizkatuz, gero Bioleta deitzen dion-. Narrazioaren amaieran bi izenek bat egiten dute maitasun istorioaren bidez -Sabine Polikarpo-, eta nolabait ere zikloa itxi egiten da.

Ikusten denez, $A Z B$ ko pertsonaiak euren ahultasun eta miseria guztiekin dira erretratatuak. Polikarpok badu Sabinoren izena, baina narrazioa amaitutakoan ere, berak ez daki -ez dakigu aitak ba ote zekien ere-. Aitak, horrela, nobela hasi eta buka, ezin du semearen aurrean duen koldar irudia ezabatu.

Lekuko historikoa da aita, bertako gazteena, Sabino Aranaren desehorzketan: "beharbada berari tokatuko zitzaiola historiaren aurrean gertaera haren lekukotza ematea" (2000:416); "Aita izan zen Sabino lurpetik atera eta bigarren ehorzketaren ibilbidea osorik egin zuen bakarra" 
(2000:424). 1989an, ordea, narrazioan orainalditzat aurkezten zaigun garaian, Arana-Goiriren gorpua atera eta Acta de exhumación de 1937 delakoa agertzen denean, aitaren izena ez da agirian agertzen. Aitak, ordura arte, "ez zuen jakin bere izena historiaren orrietatik ezabatua izan zela" (2000:417).

Agiri errealaren erreprodukzioa agertzen da Saizarbitoriaren testuan, eta horrek bidea ematen dio narratzaileari bere kritika planteatzeko. Izan ere, agiriak aipatzen dituen lekuko batzuk ez zeuden han: Ziaurritz, Ajuariagerra, eta abar; eta, aitaren hitzetan, zeuden guztiak zenbatuta ere, ez ziren dozena erdi bat ere. Polikarpok esanguratsuak diren adierazpenak egiten ditu: "Iruditzen zait agiria aldatuz historiaren aurrean berez eduki ezin izan zuen ospea eman nahi izan ziola Xemeinek zeremoniari"; edo "bere lagunen bat ez ote zuen omendu nahi izan, historiaren lehendabiziko lerroan ipiniz hain zuzen" (2000:420-421). Edonola ere, Polikarpori desegokiena iruditzen zaiona han egon zirenak ez aipatzea da. Horrela, agerian geratzen da bi klaseen arteko diferentzia: batzuek ez dute izateko arrazoirik, ez baitziren egon, baina badute izena; beste batzuek badute, han egon zirenez, izana, baina izenik ez. Otaegik dioen bezala, aipamen faltak "hace consciente al hijo de la discriminación de clase que se practica dentro del nacionalismo y que resulta totalmente incomprensible para el moribundo" (2002:161).

Hori dela eta, bere izena zergatik isildu ote zuten galdetzen dio semeak aitari, eta aitaren erantzuna azpimarratzekoa da: "ni txoferra besterik ez bainintzen" (2000:423). Banaketa horretatik eratortzen da klase diferentzia; eta aurrerago ikusten ahal da Saizarbitoriak eraikitzen duen begirada kritikoaren eta baliatzen duen tonu antiepikoaren muina (2000:234):

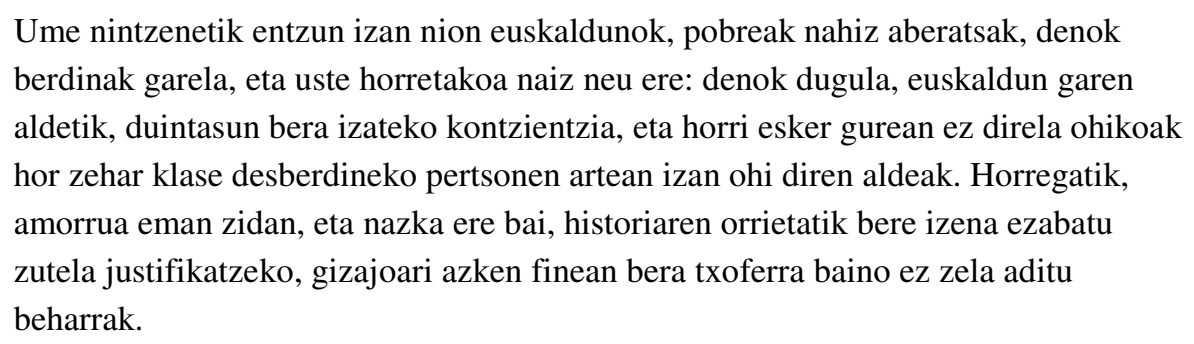

Iñaki Aldekoak dioenez, testuak "giza balio nagusi bat" erakusten du, "EAJ/PNV historikoarena izan dena, hauxe da, aberatsago edo pobreago izan, graduazioan gorago edo beherago egon, euskaldun gisa denok garela berdinak" (2009:1142). Alabaina, gure ustez ezinbestekoa da aipatzea giza balio hori nobelan markatzen duena bere ausentzia dela, eta, gisa berean, baita testuaren tonu nagusiki kritikoa ere, hain zuzen, Aldekoak "tonu ironikoa eta jostaria" (2009:1146) deitzen dion hori.

\section{Ondorioak: berrirakurketen tonua}

$A E$ eta $A Z B$ ren azterketa konparatua mahaigaineratzean memoriaz eta iraganaren berrirakurketaz ari gara, urrunekoa gaurkoarekin erlazionatzeaz. Arestian aipatu ditugu bi 
nobelen arteko antzekotasun zenbait, eta ikusi dugu diferentziak daudela berrinterpretazio historikoari dagokion tonuan.

Juan Luis Zabalaren nobelan pertsonaiak bidaia epiko batean murgiltzen dira, Lauaxetaren irudi dezente heroikoa ematen zaigu eta, Lauaxeta protagonistak iragana bere kontestutik ez ateratzeko aldarrikapena egiten badu ere, garai historikoen arteko loturak orainaldiko identitate kolektiboaren eraikuntzan zentzu positiboa -eraikitzailea- duela erakusten da.

Saizarbitoriaren nobelan, berriz, ez dago epikarik, edo, baldin badago, pertsonaiaren ahultasunak eta ezinak itzaldu egiten du ager daitekeen tonu epikoa. Polikarpok ere egiten du ezagutza bide bat, deserrotzea garaituz doa Julen Lamarain bezala, eta gainera maitasunari lotutako amaiera ona du istorioak; baina, oro har, bide horretan pertsonaiaren miseria eta ahultasun guztiek hartzen dute gaina. Zabalaren nobelan, protagonistaren deserrotzearekin batera, Lauaxeta eta euskal historia inguratzen dituen epika moduko bat dago. Aldiz, gatazkaren gaiari dagokionez Saizarbitoriak proposatzen duen korapiloan nabariagoa da denborak nabarmendu eta lehen planora eraman dituen alderdikoei egiten zaien kritika.

Beste talaia batetik, bi testuetan dago historiarekiko begirunea eta errespetua. Lauaxetari batean, Arana-Goiriri bestean, errespetuz eta ez arinki behatzen zaie. Esaterako, Polikarpori aitak erakusten dizkion Aranaren hiru argazkiek haren figura historikoa osatzen dute nolabait. Argazki batean kartzelan ageri da, borrokari gisa; bigarrenean mahaian idazten, intelektual gisa; eta azkenekoan, berriz, hilik, kaputxino jantzita, katolikotzat. AEn, Gerra Zibileko Euskadiko giroa era fidelean berreraikitzen da, eta Lauaxetaren ideologia politiko eta literarioaren ezaugarri nagusiak modu zehatzean ekarri izanak historiarekiko errespetua erakusten du.

Nobela bakoitzaren tonua markatzen duen beste ezaugarrietako bat pertsonaia modernoak iraganarekiko duen lotura da. Zabalaren protagonista nagusiak ez du iraganarekin lotura fisikorik; Lauaxeta ezagutzen du, haren mamua-edo, baina ez du familiako edo bestelako loturarik historiarekin: horrela, saltoa dago Gerra Zibileko Euskal Herriaren eta gaurkoaren artean. Horregatik, protagonista bere errelatoa eraikitzen hasten denean, irudimena da nagusi, edo hobe, imaginarioa. Eta, ezinbestean, irudimenak talka egiten du historiarekin, historiak metahistoriarekin talka egiten duen gisa berean.

Bestela gertatzen da Saizarbitoriaren narrazioan. Hor protagonistak badu lotura bat, funtsezkoa bere narrazioan: han egon zen aita. Eta han egon zen aita duen pertsonaiari ez dio imaginarioak balio. $A Z B n$ ez dago Zabalaren nobelan bezalako haustura fisiko bat. Beraz, historia berrirakurtzean, gatazka ez da sortzen imaginarioaren eta errealitatearen arteko diskordantzia posibleetatik, edo ez behintza, hortik bakarrik, baizik eta semearen eta aitaren arteko erlaziotik; izan ere, Otaegik adierazten duen bezala, "en los protagonistas, comenzando por los más nobles hasta los más mezquinos, subyace la pura necesidad de ser escuchados en el razonamiento de sus miserias y ser objeto de algún calor humano" (2002:157). Eta, gatazka horren aurrean, Otaegik berak "Asaba zaharren baratzaz oraindik" artikuluan dioenez, "[gaiak] errespetua eta 
afektua azaleratzeko parada ematen dio eta hunkidura ere bai haren ulertu ezinaren aurrean nahiz heriotzaren aurreko ahuldadean" (2002:70).

Lotura horren beharraren sinbolizazioa aitak lepotik zintzilik daraman tutuak egiten du: "noizbait nik eramango nuela lepotik zintzilik" (2000:407). Horrela, aita-semeek bat egin nahi dute, baina ez dute lortzen: continuuma badago, fisikoa, baina gatazkatsua: "oinordekotasun zaila, tokatu zaiguna" (2000:459). Mari Jose Olaziregik eta Lourdes Otaegik modu zolian erakusten dute Saizarbitoriaren testuetan oinordekotza gatazkatsu horrek suposatzen duena:

\footnotetext{
Las equivalencias que se establecen, por ejemplo, entre la lucha de los gudaris (soldados vascos) nacionalistas en el frente durante la Guerra Civil y la lucha de los miembros de E.T.A., también denominados gudaris, son solo comprensibles desde una instrumentalización de la memoria histórica de la Guerra Civil para legitimar el uso de la violencia en la actualidad. Frente a poemas como "Intxortakoak" [Los de Intxorta], de Joseba Sarrionandia donde se llama a los vascos a continuar la labor de los que cayeron en las trincheras, narraciones como las de Ramon Saizarbitoria han ahondado en la distancia que radica entre los viejos gudaris y los miembros de E.T.A. (2011:58)
}

Era berean, Polikarpok historiarekin bat egiteko zailtasunari erantzuteko duen moduak asko du antiepikatik. Narrazioaren amaieran, protagonistak Arana-Goiriren hezurtxoa uretara botatzen du, eta zama horretatik askatu bezain pronto lasaitzen da. Historiaren gogorapena zama astuna gertatzen zaio Polikarpori, eta hezur horretaz libratzeak iraganaren zamatik libratzea ere esan nahi du. Eszena esanguratsu horren interpretazioak anitzak izan dira oraino. Izaro Arroitak (2011:136) dioenez, "zu zara nire aberria" esaldiak semeak aitari bizkarra nola ematen dion iradokitzen du: “Así, Policarpo traiciona el legado de su padre y se libera del mismo declarando a su enamorada: Tú eres mi patria". Jon Kortazarrek, berriz, zera dio: "si el protagonista del relato arroja al agua el hueso de Sabino Arana es porque esa memoria colectiva, que fue la de su padre y que identificó a su padre con un grupo nacionalista, ya no le sirve para vivir, ya no es la suya, ya no es la de su grupo (2011:64). Iñaki Aldekoak ere ideia horri eusten dio:

\footnotetext{
Aurrerantzean, protagonistak bere neskalagun berria izango du aberri bakarra (“zu zara nire aberria"), alegia, ez sabino Arana eta ez hark ordezkatu zuen guztia, ez aberri galdua eta ez haren mina, "zu” ukigarria eta erreala baizik. Sabino eta sabine, arima bikiak, sukarrietako esparru paradisiakotik alde egin eta, Adan eta Evaren imitazioz, han doaz, nostalgiarik gabe eta urrats deliberatuz, biharrerantz.

Sinbolikoki, agur luzeak iraganaren oroimenetik arindutako etorkizuna iradokitzen du, modu ikaragarrian markatu baitu hark protagonistaren bizitza. Azken batean, gure arbasoen munduari esaten zaio agur. (2009:1146)
}

Baina, aldi berean, iragan guztiak ez du testuan konnotazio bera, eta gure interpretazioak ez luke iragan hori guztia lerro berean jarri behar. Izan ere, ezin da ahaztu aitaren pertsonaia klabea dela dikotomia funtsezko bat ekartzen duelako testura: aita heroi isildu bat da, loriarik gabeko heroia - gogoratu semeari jarri ziola, nahita edo nahi gabe, Sabino Aranaren izena-. Konparatu, bidenabar, Lauaxeta protagonistarekin: Lauaxeta inguratzen duen epika ez da aita inguratzen 
duena; aita txoferra zen, Lauaxeta gudaria. Eta, halere, aitarekiko errespetua nabarmendu egiten da haren beste muturrean dauden alderdikideen figura medio: horiek dira denborarekin izena lortu dutenak, Historia idatzi dutenak. Dikotomia horri erantzunez, Saizarbitoriaren testuak Historiak isiltzen dituenen historia egiten duela esan daiteke.

Beraz, ez da soilik aitaren oinordekotza traizionatzea, oroimenetik arintzea, eta memoria kolektiboaren antzutasuna nabarmentzea; irakurketa hori ez da testua osoki ulertzeko nahikoa gure ustez, aldi berean bai baitago aldarrikapen bat ere, estuki lotua "zu zara nire aberria" esaldiari eta izenburuari. Batetik, ezin da ahantzi "zu" horren irakurketa sinbolikoa, nekez esan baitaiteke pertsonen arteko maitasun aldarri hutsa denik; Otaegik Lizardiren ikuspegiaren paraleloa izan daitekeela iradokitzen du: "es el final del afecto melancólico por la pérdida, la nostalgia de lo que pierde se sublima en la confianza de que la transmisión de afecto va unida a la transmisión de la lengua y de la cutura de los pueblos y puede hacerlo perdurar" (2009:104). Bestetik, Otaegik berak gogoetatzen duen bezala (2002:75), hezurtxoak itsasoan botatzeak izan dezake isildutakoen abertzaletasunarekiko errespetu karga bat ere. Klase banaketak testuan duen presentzia kontuan hartuz, interpretazio hori bideratzen duten zantzuak badaudelakoan gaude.

Horrela bada, testuok iradokitzen digute, Ricoeurek erakutsi bezala, kontaketa literarioak aska ditzakeela kontaketa historikoak askatzen ez dituen korapiloak; era berean, interesgarria da gogoratzea Pio Perezek Josefina Cuestaren azalpenei jarraiki dioena: “oroitzeak egileari hausnarketa-espazio zehatza ahalbidetzeaz gain, justizia lekua sortarazten dio" (2013:96). Ur Apalategik, Hamaika pausoz ari delarik, azpimarratzen du Saizarbitoriaren pertsonaiaren kasuan idaztea modu mingarrian oroitzea dela: "Funtsean liburuak iradokitzen duena, idazle den pertsonaia nagusiaren figuraren bitartez, zera da, idaztea oroitzea dela, eta gehienetan gainera patologikoki oroitzea, mingarriak diren gauzatxo horiek, hitzak gehienetan, hausnartzea eta lixeritu ezinik ibiltzea" (2009:40). Oroimen kritikoak badu, baiki, minetik, eta ber gisan balio du justizia leku bat sortzeko ere.

Bestalde, azpimarratu behar da aztertutako narrazio bietako bat bera ere ez dela monologikoa. Narrazio luzeak dira, pertsonaiak biribilak dira, eta diskurtsoak ez dira alde bakarrekoak. Hain zuzen ere, Lauaxetaren pertsonaiak berak jartzen du zalantzan garai historikoak komeni bezala lotzearen zilegitasuna; horrela, imaginarioaren zorua irristakorra dela agertzen digu idazleak, eta epikatik Olaziregi eta Otaegik aipatzen duten oroimenaren instrumentalizaziora salto txikia dagoela. $A Z B \mathrm{n}$, kontrara, protagonistaren aitaren historiak badu kutsu epiko bat ere, aita txoferra, funtsean, errokonozitu gabeko heroia baita.

7 Cuesta, Josefina (2003) "Los componentes del testimonio según Paul Ricoeur” in Historia, Antropología y Fuentes Orales, 2, 41-52. 
Azken buruan, ordea, eta historiaren birsortzeak monologikoak izan ez arren, nobela bakoitza alde batera lerratzen dela esan daiteke. Gure irakurketaren arabera, Agur, Euzkadi epikaren eta antiepikaren arteko tentsioan lerratuago dago tonu epikora, eta bertan, imaginarioaren zoru irristakorra agerian geratzen den arren, oroimen kolektiboa identitate garaikidea eraikitzeko elementu beharrezko eta justifikatzaile gisa agertzen da; "Asaba zaharren baratza", aldiz, antiepikatik gertuago dago, eta, isildutako heroiei justizia egingo dien espazio bat birsortzen duen arren, protagonistak zailtasun handiak ditu iraganeko gertaerekiko jarraipen positibo eta eraikitzaile bat asmatzeko. Beharbada, tentsio ardatz horretan mugitzen da oroimen kritikoa ezinbestean; beharbada, historiaren berrirakurketa epikoa eta antiepikoa, biak dira ezinbestekoak gure identitate kolektiboaren definizio prozesuan.

\section{Erreferentziak}

Aldekoa, Iñaki. 2009. Gerra Zibila Ramon Saizarbitoriaren narraziogintzan. Euskera, monografikoa, Gerra Zibila eta euskal literatura. 1127-1147.

Apalategi, Ur. 2009. Gerra Zibila Saizarbitoriaren Bihotz bi-n: literaltasuna, alegoria eta beste zenbait hipotesi. Euskera 54(2-2). 1109-1126.

Apalategi, Ur. 2009. Zer egin 'Nouveau Roman'-aren hilotzarekin? Saizarbitoria eta birziklaia literarioa Hamaika pauso-n. Lapurdum 13. 31-42.

Arroita, Izaro. 2011. Memoria e identidad en la obra de Atxaga y Saizarbitoria. RIEV 8, Literaturas ibéricas y memoria histórica. 126-139.

Arroita, Izaro. 2015. Ramon Saizarbitoriaren nobelagintza memoria ikasketen ikuspegitik. Doktore tesia.

Askoren artean. 2008. Literatura terminoen hiztegia. Bilbo: Euskaltzaindia.

Atxaga, Bernado. 2007. Markak. Gernika 1937. Iruñea: Pamiela.

Castiñeira, Ángel. 2005. Naciones imaginadas. Identidad personal, identidad nacional y lugares de memoria. Casa encantada: Lugares de memoria en la España constitucional (1978-2004). Madril: Vervuert eta Iberoamericana.

Gurrutxaga, Alexander. 2017. Where is Basque's Harbour: From the Old Heimat to the Space of Conflict. Raum - Gefühl - Heimat: Literarische Repräsentationen nach 1945. Verlag LiteraturWissenschaft.de. 283-298.

Gurrutxaga, Alexander. 2019. Lo insólito en las representaciones literarias peninsulares de las víctimas de la Guerra Civil. Realidades fracturadas: Estéticas de lo insólito en la narrativa en lengua española (1980-2018). Madril: Visor. 29-42. 
Izagirre, Koldo. 1989. Balizko erroten erresuma. Iruñea: Susa.

Kortazar, Jon. 2009. Gerra Zibila eta euskal kontagintza. Euskera 54(2-2). 935-951.

Kortazar, Jon. 2011. Memoria y Guerra Civil en la narrativa vasca (1937-2007). Cuadernos de Alzate: revista vasca de la cultura y las ideas 45. 41-68.

Lauaxeta, Esteban Urkiaga. 1931. [faksimila 2007] Bide-barrijak. Madril: Centro de lingüística aplicada Atenea.

Olaziregi, Mari Jose. 2001. Ramon Saizarbitoriaren unibertso literarioa. Bilbo: Labayru Ikastegia.

Olaziregi, Mari Jose. 2009. La recuperación de la memoria histórica en la novela contemporánea vasca. Euskera, monografikoa, Gerra Zibila eta euskal literatura. 1027-1047.

Olaziregi, Mari Jose; Otaegi, Lourdes. 2011. La representación del bombardeo de Gernika en la literatura vasca. RIEV 8, Literaturas ibéricas y memoria histórica. 40-61.

Otaegi, Lourdes. 2002. Asaba zaharren baratzaz oraindik: Ramon Saizarbitoriaren 'Gorde nazazu lurpean' irakurtzeko modu bat. Egan 1-2. 59-78.

Otaegi, Lourdes. 2002. Escenarios literarios. Cuadernos de Alzate: revista vasca de la cultura y las ideas, 26. 137-164.

Otaegi, Lourdes. 2009. Ramón Saizarbitoria: Hamaika pauso (1995). Romane in Spanien: Band 2 - 1975-2005. Francfurt am Main: Valentia. 95-110.

Otaegi, Lourdes; Gurrutxaga, Alexander. 2019. Cuerpos ausentes y literatura: aproximación comparatística a la representación de los poetas fusilados. Los géneros de la memoria (A. Cid, C. Figueiras, F. Reyna eds.). Universidade de Santiago de Compostela: Jean Monnet Papers 2. 209-223.

Perez Aldasoro, Pio. 2013. Joxe Zapirainen bertso-malkoak, edo nola arindu arimaren sufrimenduak bertsoen bidez. Bilbo: Labayru ikastegia.

Retolaza, Iratxe. 2009. Gernikako bonbardaketa euskal literaturan: errepresentazio eta begirada poetikoak. Euskera, monografikoa, Gerra Zibila eta euskal literatura. 1079-1108.

Saizarbitoria, Ramon. 2000. Asaba zaharren baratza. Gorde nazazu lurpean. Donostia: Erein. 401-464.

Zabala, Juan Luis. 2000. Agur, Euzkadi. Iruñea: Susa. 